$\begin{array}{lll}\text { KULTURA } & \begin{array}{l}\text { POLSKA AKADEMIA NAUK } \\ \text { KOMITET SOCJOLOGII }\end{array} & \text { ISSN 0023-5172 } \\ \text { i } & \begin{array}{l}\text { INSTYTUT STUDIÓW POLITYCZNYCH } \\ \text { SPOLECLENSTWO }\end{array} & \\ \text { 2010, nr } 4 & \text { W STRONĘ PRZESZŁOŚCI }\end{array}$

PAWEE ZAEĘSKI

Instytut Filozofii i Socjologii PAN

\title{
CZY SOLIDARNOŚĆ BYŁA SPOŁECZEŃSTWEM OBYWATELSKIM? JAK ZOSTAŁ ZAPOMNIANY NEOREPUBLIKAŃSKI PROJEKT SAMORZĄDNEJ RZECZYPOSPOLITEJ
}

David Ost twierdził, że „społeczeństwo obywatelskie” stało się centralną kategorią myśli opozycyjnej w Europie Wschodniej już w latach siedemdziesiątych (Ost 1990, s. 19). Podobnie Andrew Arato źródeł dyskursu o „społeczeństwie obywatelskim" upatrywał w Polsce lat siedemdziesiątych (Arato 1993, s. 296). Jednak ściślej rzecz ujmując, po drugiej stronie żelaznej kurtyny koncepcję tę jako element autoopisu solidarnościowej opozycji importowano wiele lat po zdelegalizowaniu Związku, dopiero w drugiej połowie lat osiemdziesiątych - w miejsce wcześniejszych prób charakterystyki opozycyjnej rzeczywistości epoki schyłku realnego socjalizmu, którą definiowano w Polsce przede wszystkim poprzez neorepublikańską koncepcję samorządnej rzeczypospolitej.

Także w innych krajach bloku „społeczeństwo obywatelskie” nie było w tym czasie tak popularne, jak później. Węgier Elemer Hankiss stosował termin „drugie społeczeństwo” (Ogrodziński 1991, s. 26), jego rodak Jànos Kis (1987, s. 182) zaś określenie „sfera obywatelska”, Václav Benda w Czechosłowacji pisał o paralelnej polis obok paralelnej bądź podziemnej kultury (Rupnik 1988, s. 285). Polscy działacze proponowali samorządne społeczeństwo, samoorganizujące się społeczeństwo, paralelne społeczeństwo, podziemne społeczeństwo, równoległe społeczeństwo, alternatywne społeczeństwo, równoległe struktury, samorządną rzeczpospolitą czy społeczeństwo po prostu jako przeciwstawne rządzącym (Szacki 1997b, s. 17). Ten pozorny pluralizm miał dość ściśle zdeterminowaną historycznie ścieżkę rozwoju.

$\mathrm{W}$ gruncie rzeczy szesnaście miesięcy istnienia scentralizowanego i zhierarchizowanego Niezależnego Samorządnego Związku Zawodowego „Solidarność" było okresem oporu wobec kiełkującego głównie po drugiej stronie że-

Adres do korespondencji: pzaleski@is.uw.edu.pl 
laznej kurtyny dyskursu o tzw. społeczeństwie obywatelskim. Dyskurs o niezależnych związkach zawodowych, o ruchu związkowym, tworzeniu ogólnokrajowych struktur związkowych ewoluował w innym kierunku niż wypracowywana w tym czasie za granicą koncepcja polityczna społeczeństwa obywatelskiego. Wybieganie myślą poza zdobycz pierwszego i jedynego niezależnego samorządnego związku zawodowego należało do rzadkości. Łączenie pierwszej Solidarności z koncepcją tzw. społeczeństwa obywatelskiego jest wyłącznie reinterpretacją a posteriori. W tym czasie umysły rozpalała bowiem nie idea obywatelskości, ale idea samorządności w postaci koncepcji „samorządnego społeczeństwa” oraz przede wszystkim „samorządnej rzeczypospolitej” (Wilkanowicz 1981; Pelczynski 1988, s. 375; Gliński 2006). To właśnie koncepcja samorządnej rzeczypospolitej znalazła się w Programie NSZZ „Solidarność” uchwalonym w październiku 1981 r. przez I Krajowy Zjazd Delegatów — samorządy lokalne i pracownicze pełniły w niej kluczową rolę obok wielu innych form samorządności ${ }^{1}$.

Opis procesu tworzenia tej koncepcji został opublikowany w 31 numerze „Tygodnika Solidarność” z 30 października 1981 r. Autorem koncepcji samorządnej rzeczpospolitej był pełniący funkcję przewodniczącego Komisji Programowej Bronisław Geremek, który wypracował ją w trakcie prac komisji tematycznej zajmującej się problemem „Związek a życie publiczne”. Koncepcja, która znalazła się w jednej $z$ tez komisji, została zaproponowana przez Jana Waszkiewicza z Regionu Dolny Śląsk jako tytuł całego kluczowego szóstego rozdziału i szybko stała się, jak powiedział Jacek Kurczewski, naczelnym hasłem programu Solidarności. Jak stwierdził Geremek, samorządna rzeczpospolita „to nade wszystko samorząd w zakładzie pracy, samorząd terytorialny, lokalny - taki, który obejmowałby osiedle mieszkaniowe, ulicę, nadzór nad sklepem osiedlowym, dotyczyłby wreszcie całego systemu rad narodowych". Samorządna rzeczpospolita miała zapobiec zdiagnozowanemu przez Stefana Nowaka (1979) zatomizowaniu społeczeństwa polskiego, stanowiąc podstawę do wytworzenia więzi wspólnotowych. Koncepcja ta, zdaniem Geremka, nawiązywała do „tradycji polskiej myśli politycznej, w której naprawa Rzeczypospolitej, stan Rzeczypospolitej były hasłami reformy - [...] reformy, której cele $z$ horyzontu zakładu pracy rozszerzają się na horyzont społeczności lokalnej i wreszcie horyzont państwa”. Można zatem stwierdzić, że koncepcja samorządnej rzeczypospolitej została stworzona, ponieważ członkowie pierw-

1 Można wprost stwierdzić, że gdyby koncepcja społeczeństwa obywatelskiego była wtedy znana, musiałaby się znaleźć w dokumentach programowych. Natomiast kwestia, na ile republikańska koncepcja samorządnej rzeczypospolitej była bliska neoliberalnej koncepcji społeczeństwa obywatelskiego, może być rozstrzygnięta przez analizę, w jakim stopniu organizacje opiekuńcze są rzeczywiście samorządnymi wspólnotami, a w jakim stopniu zbiurokratyzowanymi instytucjami (zob. Załęski 2005). 
szej Solidarności zupełnie nie znali i nie stosowali koncepcji społeczeństwa obywatelskiego $^{2}$.

O braku identyfikacji z tzw. społeczeństwem obywatelskim ze strony uczestników wydarzeń sierpnia 1980 r. świadczą ówczesne socjologiczne analizy (zob. Marody i in. 1981; Touraine i in. 1982; Staniszkis 1982; Kemp-Welch 1983; Ash 1983; Krzemiński 1983, 1984; Nowak 1984; Jasiewicz 1986; Kowalski 1990). Uderzający jest absolutny brak w nich tego terminu, zwłaszcza w porównaniu z późniejszą jego popularnością. Zamiast o tzw. społeczeństwie obywatelskim pierwsze analizy, czy to apologetyczne, czy tym bardziej krytyczne, mówiły o konflikcie społecznym (Marody i in. 1981, s. 3), rewolucji (Staniszkis 1982; Ash 1983), ruchu społecznym (Touraine i in. 1982; Krzemiński 1983), zmianie społecznej, kryzysie społecznym, demokratycznej opozycji (Krzemiński 1983, s. 99, 174, 207; 1984, s. 194-195).

Wybitny badacz ruchów społecznych Alain Touraine w ogóle nie stosował wówczas do opisu Solidarności terminu société civile (Touraine i in. 1982). Także Bronisław Misztal pisząc w 1984 r. o teorii ruchów społecznych nie odnosił jej do koncepcji społeczeństwa obywatelskiego, dopiero po wyjeździe na stypendium w Stanach Zjednoczonych dokonał takiego powiązania (Misztal 1985).

Dobry przykład stanowią także pisma Jacka Kuronia, który na przełomie lat siedemdziesiątych i osiemdziesiątych pisał o samoorganizacji i podmiotowości społeczeństwa, pluralizmie, wolności stowarzyszeń, wolnościach obywatelskich, ruchach społecznych, czyli o wszystkim tym, co po upadku komunizmu powszechnie zaczęto utożsamiać z koncepcją społeczeństwa obywatelskiego jednak nie używał tego terminu (zob. Kuroń 1984a, 1984b). Niezwykle charakterystycznym przykładem jest też to, co Winicjusz Narojek (1986) w połowie lat osiemdziesiątych pisał o upaństwowionym społeczeństwie i „samorządnej rzeczypospolitej”, a dopiero osiem lat później we wstępie do drugiego wydania swej książki dokonał swoistej reinterpretacji, aplikując tam zwrot „społeczeństwo obywatelskie" (Narojek 1994, s. 6, 122).

Po wprowadzeniu stanu wojennego w grudniu 1981 r. idea samorządnej rzeczypospolitej została pozbawiona realnego sensu i została zastąpiona przez inną koncepcję. Po zdelegalizowaniu Związku dyskurs o społeczeństwie obywatelskim $\mathrm{w}$ dalszym ciągu pozostawał przytłumiony przez spór o model działalności podziemnej, wyrosły w gronie działaczy Solidarności między środowiskiem wrocławskim a Regionem Mazowsze. Jego wyrazem była zamieszczona

2 Za pośrednictwem koncepcji samorządnej rzeczypospolitej myśl programowa pierwszej Solidarności wyraziła swoje dążenie do autonomii i stworzenia własnego alternatywnego wycinka rzeczywistości w sposób odpowiadający myśli socjaldemokratycznych ruchów robotniczych z przełomu XIX i XX wieku. W tradycję dziewiętnastowiecznych ruchów robotniczych na ziemiach polskich wpisywały się zarówno solidaryzm społeczny, jak i samorządność rozumiana jako aktywność obywatelska. Ich myśl osadzona była w socjaldemokratycznej rzeczywistości rządów Jimmy’ego Cartera zdefiniowanej przez keynesizm. Nikt wówczas nie śnił o neoliberalnych przemianach zapoczątkowanych niebawem przez Ronalda Reagana i Margaret Thatcher. 
na łamach ósmego numeru „Tygodnika Mazowsze” z 31 marca 1982 r. polemika Jacka Kuronia i Zbigniewa Romaszewskiego ze Zbigniewem Bujakiem i Wiktorem Kulerskim. Dyskusja ta okazała się kluczowa dla sposobu zorganizowania działalności opozycyjnej po wprowadzeniu stanu wojennego. Kuroń proponował zlikwidowanie okupacji w zbiorowym, zorganizowanym wystąpieniu, czyli strajku generalnym. Bujak z Kulerskim natomiast przedstawili model pluralistyczny różnorodnych organizacji i środowisk, w którym Solidarność byłaby tylko jedną, choć z pewnością istotną, spośród wielu organizacji. Kulerski model ten określił mianem "społeczeństwa podziemnego" jako alternatywy wobec scentralizowanego i zhierarchizowanego Państwa Podziemnego, bliskiego temu z okresu drugiej wojny światowej, którego zwolennikiem jako formy organizacyjnej ruchu oporu był Romaszewski (Kuroń 1982; Bujak 1982; Kulerski 1982, 1986a, 1986b, 1987; Romaszewski 1987, s. 24). Kulerski obawiał się otwartej konfrontacji, wielu ofiar i nieuchronnie krwawej walki z nowym okupantem w ramach zorganizowanego państwa podziemnego. Konkurencyjną koncepcję „społeczeństwa podziemnego” stworzył w pewnym pośpiechu - jako swego rodzaju propagandową przeciwwagę dla chwytliwej koncepcji „państwa podziemnego”. Zabieg ten był udany, koncepcja „społeczeństwa podziemnego" w środowiskach opozycyjnych zdobyła szybko dużą popularność i stała się centralną dla ówczesnej myśli opozycyjnej ideą organizującą opozycyjny sposób myślenia i działania w okresie stanu wojennego ${ }^{3}$.

Kulerski znalazł szybko poparcie, na przykład ze strony Aleksandra Smolara, który swe wszystkie nadzieje pokładał w działaniu społeczeństwa podziemnego jako rozwiązania „między ugodą a powstaniem” (Smolar 1982, s. 18). Na początku lat osiemdziesiątych w Polsce nie mówiono zatem o społeczeństwie obywatelskim, lecz o społeczeństwie podziemnym ${ }^{4}$.

Tymczasowy Komitet Koordynacyjny NSZZ „Solidarność” założenia do deklaracji programowej z 28 lipca 1982 r. zatytułował właśnie „Społeczeństwo Podziemne”. I tak nakreślił sens jego istnienia: „Naszym celem jest budowa społeczeństwa samorządnego - Samorządnej Rzeczypospolitej”. W deklaracji tej społeczeństwu podziemnemu wyznaczono trzy cele: „a) uniemożliwić działania władz zmierzające do rozbicia społeczeństwa, b) wykształcić zdolność zamoorganizowania się i samoobrony, c) podnosić poziom kultury politycznej i przygotowywać społeczeństwo do życia w demokratycznej Polsce" (Bujak $\mathrm{i}$ in. 1982, s. 1). W oświadczeniu wydanym 6 września 1982 r. w związku z de-

\footnotetext{
$3 \mathrm{Na}$ podstawie wypowiedzi Kulerskiego w biograficznym filmie o nim Andrzeja Titkowa Nauczyciel z Kaczego Dotu — portret działacza Solidarności (Studio Filmowe TAK, 2008) oraz osobistego komentarza na przedpremierowym pokazie 9 maja 2008 r. Kulerski zdecydowanie stwierdził, że nie znał wówczas koncepcji społeczeństwa obywatelskiego. Można zatem wnioskować, że dlatego stworzył koncepcję społeczeństwa podziemnego.

${ }^{4}$ Jedynie wspominany już wyżej Adam Michnik (1983, s. 71) użył określenia „społeczeństwo obywatelskie”, opisując alternatywy określone przez Kuronia i Bujaka z Kulerskim.
} 
monstracjami ulicznymi TKK informował: „Zobowiązujemy ogniwa Związku do intensywnej pracy nad budową społeczeństwa podziemnego jako podstawowego środka samoobrony narodu wobec aparatu przemocy" 5 .

Po zawieszeniu stanu wojennego TKK NSZZ „Solidarność” wydał oświadczenie programowe z 22 stycznia $1983 \mathrm{r}$. W podsumowaniu można tam przeczytać:

„Tymczasowa Komisja Koordynacyjna NSZZ «Solidarność» przedstawia oświadczenie «SOLIDARNOŚĆ» DZIŚ - program działania naszego Związku w obecnych warunkach polityczno-społecznych. Czerpiemy z dziedzictwa I Krajowego Zjazdu Delegatów - z programu «Samorządnej Rzeczypospolitej». Stan wojenny i delegalizacja NSZZ «Solidarność» stworzyły nową sytuację, która stawia przed nami nowe obowiązki.

Dyskusje programowe prowadzone były w różnych środowiskach i na łamach niezależnej prasy. Ze swej strony TKK i władze regionalne inicjowały prace grup programowych. W ich toku wykrystalizowała się koncepcja Społeczeństwa Niezależnego. Wytyczyła ona główne kierunki działania. Przedstawiliśmy je w założeniach programowych "Społeczeństwo Podziemne» (lipiec 82) oraz w oświadczeniach TKK dotyczących bieżącej walki" (Bujak i in. 1983).

Kolejnym istotnym dokumentem programowym TKK był raport „NSZZ «Solidarność» na tle sytuacji politycznej, gospodarczej i społecznej Polski roku 1984" z 2 czerwca 1984 r. W rozdziale czwartym pod tytułem „Solidarność po 13 grudnia 1981 - społeczeństwo niezależne" autorzy pisali:

„Poprzez różnorodny ruch oporu realizuje się zaproponowana przez Solidarność idea społeczeństwa niezależnego, czyli takiego, w którym coraz większe grupy ludzi działają lub objęte są niezależnymi od władzy działaniami o różnym stopniu jawności. Idea społeczeństwa niezależnego jest kontynuacją $\mathrm{w}$ warunkach stanu wojennego, a obecnie ustawodawstwa wyjątkowego, programu «Solidarności» - budowy Samorządnego Społeczeństwa” 6 .

Należy również zaznaczyć, że sam Lech Wałęsa w tym czasie do koncepcji społeczeństwa obywatelskiego się w ogóle nie odwoływał, o czym świadczy treść jego przemówienia z okazji otrzymania nagrody Nobla z 11 grudnia 1983 r.

W podziemnych wydawnictwach okresu stanu wojennego, na przykład w „Tygodniku Solidarność”, „Wiadomościach”, „Tygodniku Wojennym”, „Tygodniku Mazowsze”, próżno szukać terminu „społeczeństwo obywatelskie”. Dominowała wówczas retoryka wojenno-podziemna posługująca się koncepcjami państwa podziemnego, społeczeństwa podziemnego czy podziemnego ruchu, ruchu podziemnego oporu albo po prostu podziemia. Po zawieszeniu

\footnotetext{
5 „Tygodnik Mazowsze”, 15 września 1982.

6 Biuletyn Informacyjny Biura Koordynacyjnego NSZZ „Solidarność” za Granicą, nr 93, 8 sierpnia 1984.
} 
stanu wojennego myśl opozycyjna ewoluowała w kierunku retoryki społeczeństwa niezależnego i samorządnego ${ }^{7}$.

W bardziej wypracowany sposób termin „społeczeństwo obywatelskie” $\mathrm{w}$ środowisku intelektualistów sympatyzujących z solidarnościową opozycją jako pierwszy zaczął stosować $\mathrm{w}$ nowym ponowoczesnym znaczeniu Ireneusz Krzemiński - wiążąc go bezpośrednio z działalnością pierwszej Solidarności z początku lat osiemdziesiątych. Zwrot „społeczeństwo obywatelskie” do słownika tego autora wszedł dopiero w 1985 r., a zawdzięczał to — jak później pisał (Krzemiński 1997, s. 12) - Davidowi Ostowi oraz Michaelowi Bernhardowi. Twierdzenie to mówi wprost, że koncepcja społeczeństwa obywtelskiego została wypracowana poza granicami Polski i dopiero wtórnie importowana przez polskich akademików, a następnie opozycjonistów ${ }^{8}$.

Wtedy zatem Krzemiński uznał, że „podstawową sprawą i kategorią, która pozwala ująć jak w soczewce główny kierunek dążeń społecznych «Solidarności», jest idea SPOŁECZEŃSTWA OBYWATELSKIEGO”. Zdefiniował przy tym „społeczeństwo obywatelskie” jako „wspólnotę obywateli”, czyli „węzeł,

${ }^{7}$ Nie tylko jednak na poziomie semantycznym, ale również strukturalnym można uzasadnić brak związku między neorepublikanizmem pierwszej Solidarności a neoliberalnym projektem społeczeństwa obywatelskiego. Jak zauważył Marcin Król, uczestnictwo w ruchu opozycyjnym miało charakter korporacyjny, a nie stowarzyszeniowy: „Powstawały wspólnoty, lecz nie społeczeństwo obywatelskie respektujące rządy prawa (o których przecież nie mogło być mowy), autonomię jednostki (właśnie zachowania indywidualistyczne, niezgodne z opozycyjnymi wzorcami były potępiane) i traktujące wszystkich jako potencjalnie równoprawnych (nie każdy mógł być członkiem opozycji)" (Król 1993, s. 111).

8 W 1983 r. w odniesieniu do Solidarności Krzemiński pisał o „podmiotowym byciu członkiem społeczeństwa", o prawie do występowania w roli obywatela, poczuciu wspólnoty, solidarności społecznej, sieci nieformalnych kontaktów społecznych i demokratycznej opozycji, ale ani razu nie wymienił terminu „społeczeństwo obywatelskie” (zob. Krzemiński 1983, s. 86, 88, 103, 132, $174,282)$. Nie użył terminu „społeczeństwo obywatelskie” również wtedy, gdy pisał o demokratycznej opozycji jako „obszarze społecznej wolności” w artykule z roku 1984 (Krzemiński 1984, s. 194-195). Należy stwierdzić, że jeszcze w 1984 r. Krzemiński raczej go nie stosował, a na przedstawienie wyników badań z 1983 r. dopiero w 1985 r., jak już powiedziano, znalazł nazwę w postaci terminu „społeczeństwo obywatelskie”, stając się w ten sposób jego prekursorem w Polsce. Warto podkreślić przy tym, że jeszcze w 1987 r. nie pisał o Solidarności bezpośrednio jako o tzw. społeczeństwie obywatelskim, ale że „wcielała i formowała” jego ideę, ideę nową i dla autora, i dla potencjalnych czytelników. Jednak w wydanej w 1987 r. książce tezę, że Solidarność wcielała i formowała ideę „społeczeństwa obywatelskiego”, przypisał swym rozważaniom zarówno z roku 1983, jak i 1985, przy czym pierwsze określił jako rozważania stanowiące hipotezę, a drugie jako już sformułowane w „wyraźniejszej formie” (Krzemiński 1987a, s. 1). Jest to doskonały przykład procesu autobiograficznej reinterpretacji, charakterystycznej dla większości opozycyjnych intelektualistów, retrospektywnie wiążących koncepcję społeczeństwa obywatelskiego z pierwszą Solidarnością (zob. Hałas 1992). Stosując metodę autobiograficzną uzyskuje się opis przeszłości w kategoriach zaczerpniętych z teraźniejszości - to jedna z przyczyn tego, że bardziej obiektywnym narzędziem badania historii koncepcji społeczeństwa obywatelskiego wydaje się niereaktywna analiza materiałów zastanych niż na przykład źródłotwórcze wywiady z uczestnikami wydarzeń uzyskane wyniki są zaskakująco odmienne od ugruntowanej opinii. Ludzka pamięć nie jest bowiem tożsama $\mathrm{z}$ historią. 
wiążący prawa i interesy jednostki z interesami i prawami innych" w kategorii „dobra wspólnego” (Krzemiński 1985, s. 15, 18). Neorepublikański charakter manifestu Krzemińskiego był bliski ideałom pierwszej Solidarności, jednak daleki od neoliberalizmu drugiej ${ }^{9}$.

Prace Krzemińskiego posłużyły ścisłemu powiązaniu pierwszej Solidarności z koncepcją społeczeństwa obywatelskiego. Odzwierciedla to proces zawłaszczenia dyskursu o związku zawodowym „Solidarność” przez intelektualistów (rozpoczęty przez próbującą przejąć władzę w ruchu frakcję tzw. korników ${ }^{10}$ ), co miało decydującą rolę $\mathrm{w}$ przesłonięciu centralnej roli robotników w jego tworzeniu, jak stwierdził po latach Rafał Matyja (2005).

Należy jednak dodać, że w tym samym 1985 r. koncepcja społeczeństwa obywatelskiego znalazła się również $\mathrm{w}$ analizach innego socjologa - związanego z reżimem Jerzego Wiatra, który stosował ją w znacznie bardziej zbliżonym do później spopularyzowanego neoliberalnym rozumieniu (Wiatr 1985, s. 60; zob. Załęski 2007).

Publikacje Wiatra i Krzemińskiego z 1985 r. ukazały się w pewnym sensie nieco przedwcześnie, stanowiąc jednak przyczynek do późniejszego rozwoju semantyki społeczeństwa obywatelskiego w Polsce. Dominująca od 1982 r. semantyka społeczeństwa podziemnego wyczerpała się w obliczu wrześniowej amnestii z 1986 r. ${ }^{11}$ Wtedy Kulerski napisał, że mimo zwolnienia więźniów „podziemne społeczeństwo powinno istnieć” - ale mimo przywiązania Kulerskiego do koncepcji był to symboliczny koniec tej semantyki (Kulerski 1986a, s. 1, 3). W następnym roku Kulerski stwierdził: „Być może zbliżamy się do etapu, w którym istotnie określenie «społeczeństwo niezależne» będzie bar-

9 Była to koncepcja daleka od neoliberalnej retoryki, która doszła do głosu kilka lat później w programie drugiej Solidarności, gdy uznano, że istotą polityki jest walka interesów oraz zawsze tymczasowe alianse i kompromisy. Neorepublikańska koncepcja dobra wspólnego ma wiele elementów wspólnych z ideą mieszczącą się w ramach komunistycznego logosu, sformułowaną w postaci moralnej zasady kolektywizmu — jak sugeruje Andrzej Walicki, krytykujący pierwszą Solidarność jako projekt odbiegający od zasad liberalnych, a także Paweł Śpiewak kreślący wizję roli tej koncepcji w systemach totalitarnych (zob. Walicki 1984; Śpiewak 1998, s. 5-6). Po drugiej stronie żelaznej kurtyny koncepcję „społeczeństwa obywatelskiego” konceptualizowano w bardziej pluralistyczny i neoliberalny sposób (np. Arato 1981; Markus 1985; Bielasiak 1985; Szajkowski 1985). W wersji neoliberalnej demokracja nie jest utożsamiana ze wspólnotą, stanowi raczej mechanizm regulowania różnic. Vincent Ostrom (1994) nazwał to systemem otwartym na konflikt i jego rozwiązywanie. W $1987 \mathrm{r}$. w programie drugiej Solidarności zagościły propozycje prywatyzacji ekonomii - w tym samym czasie, co w retoryce rządzącego reżimu, czyli po przystąpieniu Polski do układu z Bretton Woods (Ost 1990, s. 168). Pierwsza Solidarność z drugą były programowo nieporównywalne, jak idealizm z pragmatyzmem.

10 Czyli akademików z Komitetu Obrony Robotników, którzy w większości do Solidarności formalnie nie należeli, pełniąc zwykle nieco asekuracyjną rolę doradców, a nie członków związku. Można ich zatem określać najwyżej jako sympatyków Solidarności, a nie jej uczestników.

11 Będącej jednym z warunków negocjacji z Międzynarodowym Funduszem Walutowym, do którego Polska przystąpiła w tym samym roku. Można w tym miejscu postawić tezę, że upadek systemu komunistycznego był już elementem neoliberalnego projektu ponowoczesności. 
dziej odpowiadało rzeczywistości niż określenie "społeczeństwo podziemne»" (Kulerski 1987, s. 88). W nowej sytuacji politycznej dotychczasowy paradygmat zdezaktualizował się i rozgorzała dyskusja o kształt i rolę Solidarności. Wtedy zamiast o społeczeństwie podziemnym zaczęto mówić o społeczeństwie obywatelskim. Tym samym z czysto akademickiego dyskursu termin „społeczeństwo obywatelskie" przeniknął do dyskursu politycznego. Jednocześnie jednak oznaczało to odsunięcie w niepamięć idei samorządności i samorządnego społeczeństwa z okresu pierwszej Solidarności na rzecz liberalnie pojmowanego pluralistycznego społeczeństwa obywatelskiego.

W styczniu 1987 r. ukazał się komunikat świeżo utworzonej Tymczasowej Rady NSZZ „Solidarność” przedstawiający zarys dyskusji na temat kształtu i roli Solidarności w nowej sytuacji politycznej: „Dyskutowano na temat zakresu i trybu prac zmierzających do skupienia członków Związku i całego społeczeństwa obywatelskiego wokół programu mającego przeciwdziałać stagnacji gospodarczej, degradacji naturalnego środowiska, dewastacji zasobów kraju i pogarszającym się warunkom życia" (Bujak i in. 1987, s. 1). Wtedy prawdopodobnie pierwszy raz $\mathrm{w}$ oficjalnym języku politycznej opozycji pojawiła się koncepcja społeczeństwa obywatelskiego.

W wydawanych w tym roku komunikatach powstałej w Gdańsku Krajowej Komisji Wykonawczej można dostrzec stopniowe odchodzenie od dotychczas ściśle politycznego rozumienia terminu „społeczeństwo obywatelskie”. Pod koniec października 1987 r. KKW jeszcze pisała: „Pozostaje nam uporczywa walka o to, by społeczeństwo polskie stało się w pełni społeczeństwem obywatelskim. Aby urzeczywistniony został pluralizm polityczny, gospodarczy i związkowy" (Wałęsa i in. 1987a, s. 1). Na początku grudnia czytamy już o „legalizacji społeczeństwa obywatelskiego, w którym respektowane są i realizowane prawa podmiotowe człowieka, a zwłaszcza swoboda formowania i rejestracji stowarzyszeń" (Wałęsa i in. 1987b, s. 1).

W 1988 r. w obliczu rozmów nawiązanych między stroną rządową a opozycją i przygotowań do Okrągłego Stołu retoryka społeczeństwa obywatelskiego zniknęła z dyskursu Solidarności. W 1989 r. zaś termin „społeczeństwo obywatelskie" wszedł do oficjalnego dyskursu politycznego reżimu komunistycznego (Załęski 2007), był bowiem dobrze komunistom znany. Przed rokiem 1989 można go było spotkać głównie w dziełach Marksa i Engelsa. Termin ten jest bowiem wynalazkiem komunistycznej cenzury, która w 1949 r. wprowadziła go do tłumaczeń Marksa w miejsce terminu „społeczeństwo cywilne” (Załęski 2008). A w przełomowym roku 1989 to nie Solidarność, ale komunistyczna propaganda doprowadziła do spopularyzowania tej koncepcji (Załęski 2007). Dyskurs politycznej opozycji zgrupowanej pod szyldem Solidarności stanowił tylko jeden $z$ etapów rozwoju ponowoczesnej semantyki społeczeństwa obywatelskiego.

W ramach kompromisu Okrągłego Stołu społeczeństwo obywatelskie zaoferowano zamiast suwerennego i pełnoprawnego społeczeństwa politycznego. 
Proces ten blisko rok wcześniej zapowiadał jeden $z$ głównych projektantów rozmów Okrągłego Stołu Bronisław Geremek, który w maju 1988 r. uzasadniał, że „W chwili obecnej tendencją rozwojową fenomenu opozycji polskiej — który sam chętniej bym nazwał fenomenem polskiego społeczeństwa cywilnego, społeczeństwa obywatelskiego - jest rozwijanie pluralizmu społecznego i pluralizmu gospodarczego przy rezygnacji z pluralizmu politycznego" (Geremek 1988, s. 4). Neoliberalny kompromis drugiej Solidarności, zogniskowany w koncepcji społeczeństwa obywatelskiego, doprowadził do zatracenia neorepublikańskiego projektu polityczności wypracowanego za czasów pierwszej Solidarności poprzez koncepcję samorządnej rzeczypospolitej. Polska była jedynym krajem bloku, w którym nie doszło od razu do pełni reform politycznych.

Neoliberalne przemiany rozpoczęły się w Polsce zanim w ogóle doszło do jakichkolwiek negocjacji między reżimem a opozycją. Ustawę o fundacjach ogłoszono 6 kwietnia 1984 r., w 1986 r. komunistyczny reżim wprowadził Polskę do Międzynarodowego Funduszu Walutowego, a w 1988 r. zliberalizowano ekonomię dzięki ustawie o działalności gospodarczej, opracowanej według projektu ministra przemysłu Mieczysława Wilczka i premiera Mieczysława Rakowskiego. Tak zwana transformacja ustrojowa na początku dotyczyła głównie ekonomii i trzeciego sektora, nie mając w ogóle charakteru przemian demokratycznych o charakterze politycznym. Ustawę o stowarzyszeniach z 4 kwietnia 1989 r., tak samo jak reformy gospodarcze, wprowadzono odgórnie, bez społecznych konsultacji, głosami tzw. sejmu kontraktowego, który został wybrany w nie w pełni demokratycznych wyborach 4 czerwca 1989 r. Dziesięć ustaw składających się na neoliberalny plan Balcerowicza zostało uchwalonych 28 grudnia $1989 \mathrm{r}$. przez ten sejm. Ustawy te podpisal prezydent, którego w ogóle nikt nie wybierał - Wojciech Jaruzelski, który dopiero w grudniu 1990 r. został zastapiony przez demokratycznie wybranego prezydenta Lecha Wałęsę. Pierwsze wybory do parlamentu w warunkach prawdziwej demokracji zostały przeprowadzone dopiero 27 października 1991 r. Depolityzacja społeczeństwa polskiego była jednym z głównych efektów transformacji, w wyniku której sprawą priorytetową stało się ekonomiczne przeżycie, a nie polityczne zaangażowanie szerokich mas społecznych. Praca w trzecim sektorze stała się w tym czasie źródłem absorpcji zachodnich funduszy (zob. Załęski 2005).

Nikt nie poważył się jeszcze podjąć monumentalnej, ze względu na globalny wymiar tematu, pracy zbadania, czy i w jakim stopniu neoliberalna koncepcja społeczeństwa obywatelskiego jest istotna i jaką rolę odgrywa we współczesnym dyskursie politycznym. Jakikolwiek byłby stan bieżący, nie ma badań, które potwierdzałyby obiegową i często powtarzaną opinię, że miał on cokolwiek wspólnego z neorepublikańskim doświadczeniem pierwszej Solidarności. A powyższe analizy materiałów zastanych tę opinię wyraźnie podważają. 


\section{BIBLIOGRAFIA}

Arato Andrew, 1991, Civil Society against the State: Poland, 1980-1981, „Telos”, t. 47, s. 23-47.

Arato Andrew, 1993, From Neo-Marxism to Democratic Theory: Essays on the Critical Theory of Soviet-Type Societies, M.E. Sharpe, Armonk.

Ash Timothy, 1983, The Polish Revolution: Solidarity 1980-82, Jonathan Cape, London.

Bielasiak Jack, 1985, Solidarity and the State: Strategies of Social Reconstruction, w: Bronisław Misztal (red.), 1985, Poland after Solidarity: Social Movements versus the State, Transaction Books, New Brunswick.

Bujak Zbigniew 1982, Walka pozycyjna, „Tygodnik Mazowsze”, 31 marca.

Bujak Zbigniew i in., 1982, Społeczeństwo podziemne: Wstępne założenia deklaracji programowej TKK NSZZ „Solidarnośc”, „Tygodnik Mazowsze”, 28 lipca.

Bujak Zbigniew i in., 1983, „Solidarność” dziś. Oświadczenie programowe Tymczasowej Komisji Koordynacyjnej NSZZ „Solidarność, „Tygodnik Mazowsze”, 27 stycznia.

Bujak Zbigniew i in., 1987, Komunikat Tymczasowej Rady NSZZ „Solidarnośc”, „Tygodnik Mazowsze", 21 stycznia.

Geremek Bronisław, 1988, Opozycja '91, „Res Publica”, nr 5.

Gliński Piotr, 2006, The Self-governing Republic in the Third Republic, „Polish Sociological Review", nr 1.

Hałas Elżbieta, 1992, Konwersja. Perspektywa socjologiczna, Norbertinum, Lublin.

Jasiewicz Krzysztof, 1986, Przemiany świadomości społecznej Polaków 1979-1983, „Aneks”, nr 32.

Keane John (red.), 1988, Civil Society and the State: New European Perspectives, Verso, London.

Kemp-Welch Anthony, 1983, The Birth of Solidarity, Macmillan, London.

Kis Jànos, 1987, W póttora roku później, o tym samym, „Krytyka”, nr 25.

Kowalski Sergiusz, 1990, Krytyka solidarnościowego rozumu. Studium z socjologii myślenia potocznego, PEN, Warszawa.

Król Marcin, 1993, Między korporacją a społeczeństwem obywatelskim, w: Barbara Markiewicz (red.), Obywatel: odrodzenie pojęcia, IFiS PAN, Warszawa.

Krzemiński Ireneusz (red.), 1983, Polacy — jesień 80. Proces powstawania niezależnych organizacji zwiazkowych, IS UW, Warszawa.

Krzemiński Ireneusz, 1984, System społeczny epoki gierkowskiej, w: Stefan Nowak (red.), Społeczeństwo polskie czasu kryzysu. Przeobrażenia świadomości $i$ warianty zachowań, IS UW, Warszawa.

Krzemiński, Ireneusz 1985, „Solidarność” — sens ludzkiego doświadczenia, „Przegląd Polityczny”, nr 6 (druga wersja: „Aneks”, nr 40).

Krzemiński Ireneusz, 1986, Świat zakorzeniony, „Przegląd Polityczny”, nr 7.

Krzemiński, Ireneusz 1987a, Czego chcieli, o czym myśleli? Analiza postulatów robotników wybrzeża z 1970 i 1980, IS UW, Warszawa.

Krzemiński Ireneusz, 1987b, Świat zakorzeniony, „Aneks”, nr 43.

Krzemiński Ireneusz, 1987c, Religia i „Solidarnośc”, „Aneks”, nr 48.

Krzemiński Ireneusz, 1988, Religia a ruch społeczny „Solidarnośc”, „Przegląd Polityczny”, nr 10.

Krzemiński Ireneusz, 1997, Solidarność. Projekt polskiej demokracji, Oficyna Naukowa, Warszawa. 
Kulerski Wiktor, 1982, Trzecia możliwość, „Tygodnik Mazowsze”, 31 marca.

Kulerski Wiktor, 1986a, Społeczeństwo podziemne powinno istnieć, „Tygodnik Mazowsze”, 24 września.

Kulerski Wiktor, 1986b, Społeczeństwo podziemne, „Kultura Niezależna” nr 19.

Kulerski Wiktor, 1987, Społeczeństwo podziemne 1987, „Kultura”, nr 4.

Kuroń Jacek, 1982, Tezy o wyjściu z sytuacji bez wyjścia, „Tygodnik Mazowsze”, 31 marca.

Kuroń Jacek, 1984a, Zło, które czynię, Niezależna Oficyna Wydawnicza, Warszawa.

Kuroń Jacek, 1984b, Polityka i odpowiedzialność, Aneks, London.

Markus Maria, 1985, Constitution and Functioning of Civil Society in Poland, w: Bronisław

Misztal (red.), 1985, Poland after Solidarity: Social Movements versus the State, Transaction Books, New Brunswick.

Marody Mirosława i in., 1981, Polacy '80, Instytut Socjologii UW, Warszawa.

Matyja Rafał, 2005, Wzniosła i gorzka rocznica: Czy potrafimy przemyśleć „Solidarnośc”, „Fakt-Europa", 7 września.

Michnik Adam, 1983, Analiza i perspektywy, „Kultura”, nr 7-8.

Misztal Bronisław (red.), 1985, Poland after Solidarity: Social Movements versus the State, Transaction Books, New Brunswick.

Narojek Winicjusz, 1986, Perspektywy pluralizmu w upaństwowionym społeczeństwie, Aneks, London.

Narojek Winicjusz, 1994, Perspektywy pluralizmu w upaństwowionym spoteczeństwie, ISP PAN, Warszawa.

Nowak Stefan, 1979, System wartości spoteczeństwa polskiego, „Przegląd Socjologiczny”, nr 4.

Nowak Stefan (red.), 1984, Społeczeństwo polskie czasu kryzysu. Przeobrażenia świadomości $i$ warianty zachowań, IS UW, Warszawa.

Ogrodziński Piotr, 1991, Pięć tekstów o społeczeństwie obywatelskim, ISP PAN, Warszawa.

Ost David, 1990, Solidarity and the Politics of Anti-Politics: Opposition and Reform in Poland since 1968, Temple University Press, Philadephia.

Ostrom Vincent, 1994, Federalizm amerykański. Tworzenie społeczeństwa samorzadnego, Polskie Towarzystwo Psychologiczne, Warszawa.

Pelczynski Zbigniew, 1988, „Solidarity” and „The Rebirth of Civil Society” in Poland, w: John Keane (red.), Civil Society and the State: New European Perspectives, Verso, London.

Romaszewski Zbigniew, 1987, Bezdroża „Solidarności”, „Kultura”, nr 1-2.

Rupnik Jacques, 1988, Totalitarianism Revisited, w: John Keane (red.), Civil Society and the State: New European Perspectives, Verso, London.

Smolar Aleksander, 1982, Między ugoda a powstaniem, „Aneks”, nr 28.

Staniszkis Jadwiga, 1982, Pologne: la révolution autolimitée, Press Universitaires de France, Paris.

Szacki Jerzy (red.), 1997a, Ani książe, ani kupiec: obywatel. Idea społeczeństwa obywatelskiego w myśli wspótczesnej, Znak, Kraków.

Szacki Jerzy, 1997b, Wstęp. Powrót idei społeczeństwa obywatelskiego, w: Jerzy Szacki, Ani książę, ani kupiec: obywatel. Idea społeczeństwa obywatelskiego w myśli współczesnej, Znak, Kraków.

Szajkowski Bogdan, 1985, The Catholic Church in Defense of Civil Society in Poland, w: Bronisław Misztal (red.), 1985, Poland after Solidarity: Social Movements versus the State, Transaction Books, New Brunswick.

Śpiewak Paweł, 1998, W stronę wspólnego dobra, Fundacja Aletheia, Warszawa. 
Śpiewak Paweł, 2005, Do czego może stużyć „Solidarność” w liberalnym świecie, „Fakt-Europa", 7 września.

Touraine Alain i in., 1982, Solidarité: Analyse d'un mouvement social, Pologne 1980-1981, Fayard, Paris.

Walicki Andrzej, 1984, Myśl o sytuacji politycznej i moralno-psychologicznej w Polsce, „Aneks”, nr 35.

Wałęsa Lech i in., 1987a, Stanowisko w sprawie referendum, „Tygodnik Mazowsze”, 28 października.

Wałęsa Lech i in., 1987b, Oświadczenie KKW, „Tygodnik Mazowsze”, 9 grudnia.

Wiatr Jerzy, 1985, Wspótczesne treści marksowskiej teorii państwa, „Studia Socjologiczne”, nr 3-4.

Wilkanowicz Stefan, 1981, Ku Polsce samorzadowej, „Tygodnik Solidarność”, 4 września.

Załęski Paweł, 2005, Globalny system pozarzadowej administracji. Geosocjologia trzeciego sektora, „Studia Polityczne”, nr 17.

Załęski Paweł, 2007, Propaganda społeczeństwa obywatelskiego $w$ dobie transformacji. Zestawienie zawartości materiałów prasowych, „Zeszyty Prasoznawcze”, nr 3-4.

Załęski Paweł, 2008, Etymologia spoteczeństwa obywatelskiego. O problemie tłumaczenia nowoczesnej koncepcji bürgerliche Gesellschaft, „Acta Philologica”, nr 34.

\section{WAS THE SOLIDARITY A CIVIL SOCIETY? \\ HOW THE NEO-REPUBLICAN PROJECT OF SELF-GOVERNING PEOPLE WAS FORGOTTEN}

\section{Summary}

Analysis of the extant data, such as opposition press and documents, shows that participants of the first Solidarity did not know or use the concept of civil society. The dynamics of discourse of the first Solidarity found its climax instead in the concept of the self-governing Republic. Only in 1987, after a general amnesty for political prisoners, the concept of civil society was adopted, replacing the concept of the underground society which had been current under Martial Law. Thus, the neoliberal concept of civil society displaced the concept of self-governing Republic.

\section{Key words/słowa kluczowe}

self-governing Republic / samorządna rzeczpospolita; underground society / społeczeństwo podziemmne; civil society / społeczeństwo obywatelskie; neorepublicanism / neorepublikanizm; neoliberalism / neoliberalizm 